\title{
Terapi Relaksasi Otot Progresif Sebagai Alternatif Mengatasi Stress Dimasa Pandemi Covid-19 Di Kabupaten Lombok Tengah
}

\author{
Lalu Mutawalli, Sabar Setiawan, Saimi \\ Program Studi Magister Administrasi dan Kebijakan Kesehatan \\ Universitas Qamarul Huda Badaruddin \\ Email: lalumutawallihafiz520@gmail.com
}

\begin{abstract}
Abstrak. Coronavirus Disease 2019 (COVID-19) pertama kali ditemukan Wuhan Provinsi Hubei, Cina, penyebarannya dan transmisi COVID-19 sangat cepat hingga WHO menetapkan COVID-19 sebagai kasus pandemi global. Meluasnya penyebaran COVID-19 di Indonesia sangat cepat. Berdasarkan data WHO kasus COVID-19 di dunia sebanyak 6,535,354, kasus dengan kematian 387,155 jiwa. 216 negara termasuk Indonesia telah terpapar virus ini. Di Indonesia kasus positive COVID-19 sebanyak 29,521 kasus positive dengan 1770 kematian, dan di NTB sebanyak 798 kasus dengan 22 kematian, dan tingginya kasus ini menyebabkan masyarakat mengalami strees berat baik akibat pikiran maupun bebean kerja selama pandemic COVID-19. Desain penelitian dalam penelitian ini adalah Quasy Experiment Design .Penelitian ini jumlah sampel dalam penelitian ini sebanyak 36 responden yang diambil dengan teknik purposive sampling. Dan tujuan penelitian ini adalah melihat pengaruh dari pengaruh teknik relaksasi otot progresif terhadap penurunan tingkat stress masyarakat kabupaten Lombok Tengah. Berdasarkan hasil uji statistik, dapat diperoleh nilai rata-rata skor tingkat stress sebelum intervensi sebanyak 16,75 dan mengalami penurunan skor stress setelah diberikan intervensi teknik relaksasi otot progresif 11,58. Nilai rata-rata skor stress masyarakat menunjukan adanya penurunan setelah diberikan terapi teknik relaksasi otot progresif 5,16 dengan p value 0,000 lebih kecil dari $\alpha=0,05$. Kesimpulan penelitian ini adalah artinya ada pengaruh yang signifikan pemberian terapi teknik relaksasi otot progresif terhadap penurunan tingkat stress masyarakat dimasa pandemic COVID-19 di Kabupaten Lombok Tengah.
\end{abstract}

Kata Kunci: Relaksasi Otot Progresif, Stress, COVID-19

\section{PENDAHULUAN}

Coronavirus Disease 2019 (COVID-19) pertama kali ditemukan Wuhan Provinsi Hubei, Cina, penyebarannya dan transmisi COVID-19 sangat cepat hingga WHO menetapkan COVID-19 sebagai kasus pandemi global. Meluasnya penyebaran COVID-19 di Indonesia sangat cepat. Berdasarkan data WHO kasus COVID-19 di dunia sebanyak 6,535,354, kasus dengan kematian 387,155 jiwa. 216 negara termasuk Indonesia telah terpapar virus ini. Di Indonesia kasus positive COVID-19 sebanyak 29,521 kasus positive dengan 1770 kematian, dan di NTB sebanyak 798 kasus dengan 22 kematian (WHO, 2020;Dinkes NTB, 2020).
Penyebaran Kasus ini berdampak bagi tatanan kehidupan masyarakat, oleh karena itu untuk meminimalisir penularan banyak hal yang harus diperhatikan, karena kasus ini mengakibatkan gangguan psikologi masyarakat Indonesia berupa kecemasan yang berlebihan. Keadaan ini semakin diperparah oleh kurangnya pengetahuan masyarakat tentang COVID-19(Ausrianti, et.,al 2020; Mona, 2020).

Kurangnya pengetahuan masyarakat menyebabkan masyarakat tidak dapat merespon dengan baik keadaan yang terjadi, sehingga cenderung menimbulakn stress, yang diakibatkan masyarakat tidak bisa beraktivitas diluar rumah, pekerjaan yang menunmpuk 
semenjak kebiajakan work from home diberlakukan. Peneitian yang dilakukan oleh Purwanto (2020) menyatakan salah satu pemicu stres ialah menumpuknya pekerjaan yang harus diselesaikan. Apabila masyarakat memiliki tipe yang dapat mengelola waktu dengan baik, Work From Home tentu tidak akan menjadi masalah.Ketika stres yang dirasa tak menjadi beban, tentu saja produktivitas kerja akan menjadi meningkat, tetapi malah sebaliknya.

Stres adalah suatu respon adaptif, yang dipengaruhi oleh perbedaan individual dan atau proses psikologis, yang merupakan konsekuensi dari aksi ekternal (lingkungan), situasi atau peristiwa yang mengakibatkan ketegangan psikologis dan atau fisik terhadap seseorang. Aksi eksternal, peristiwa dan situasi dikenal sebagai sumber stres (Ivancevich, Konopaske, \& Matteson, 2006)

Salah satu bentuk stres yang dapat menimbulkan gangguan kejiwaan kecuali kecemasan (ansietas) adalah juga yang dinamakan depresi. Baik kecemasan maupun depresi kedua-duanya mempunyai gejala-gejala gangguan fungsi dari organ-organ tubuh yang dipersarafi oleh sistem saraf otonom. Menurut Arisjulyanto (2017) stress bisa menyebabkan penyempitan pembuluh darah dan kekakuan otot yang dampaknya terhadap peningkatan tekanan darah sehingga memicu terjadinya hipertensi, dalam mengatasi masalah ini pentingnya pemberian terapi yang mudah diterapkan dan mampu menangani masalah stress yang terjadi di tengah wabah pandemic COVID-19 seperti saat ini (Muslimin, 2017;Arisjulyanto, 2018).

Penelitian yang dilakukan oleh Arisjulyanto (2017) menunjukan teknik relaksasi otot progresive merupakan terapi alternative yang mudah dan mampu menurunkan stress dan tekanan darah tinggi. Penelitian ini didukung juga oleh penelitian(Lestari \& Yuswiyanti (2015) menunjukan bahwa teknik relaksasi otot progresif mempu menurunkan kecemasan dan stress pasien, sehinggi teknik relaksasi ini sangat dianjurkan untuk dilaksanakkan dalam menangani masalah stress dimasa pandemic COVID-19.

penelitian Ilmi, Dewi, \& Rasni (2017) menyatakan bahwa teknik relaksasi mampu menurunkan stress pasien. Dikarenakan relaksasi. Otot progressive merupakan Salah satu bentuk relaksasi otot secara progresif dengan dan tanpa ketagangan otot dan teknik manipulasi pikiran mengurangi komponen fisiologis dan emosional stresTeknik relaksasi ini akan mengurangi ketegangan dan parameter fisiologis akan berubah.

Berdasarkan uraian diatas maka pentingnya dilakukan penelitian ini sebagai salah satu bentuk penanganan stress dimasa pandemic COVID-19.

\section{METODE PENELITIAN}

Desain penelitian yang digunakan dalam penelitian ini adalah penelitian one group pretest postets design .Penelitian ini melakukan pengukuran tingkat stress masyarakat sebanyak dua kali yaitu sebelum dan sesudah diberikan terapi pijat marmet. jumlah sampel dalam penelitian ini sebanyak 36 responden yang diambil dengan teknik purposive sampling. Penelitian ini dillaksakan di Kabupaten Lombok Tengah dan tujuan penelitian ini adalah melihat pengaruh dari terapi relaksasi otot progresif terhadap tingkat stress masyarakat dimasa pandemic COVID-19.

\section{HASIL Dan PEMBAHASAN \\ Karakteristik Responden}

Tabel 1. Karekteristik responden

\begin{tabular}{lcc}
\hline Variabel & n & \% \\
\hline Jenis & & \\
Kelamin & 15 & 41,66 \\
Laki-laki & 21 & 58,33 \\
Perempuan & & \\
Pendidikan & & \\
Tidak & 6 & 16,66 \\
Sekolah & 2 & 5,55 \\
SD & 3 & 8,33 \\
SMP & 13 & 36,11 \\
SMA & 12 & 33,33 \\
S1 & & \\
\hline
\end{tabular}


Berdasarkan data pada Tabel 1 jenis kelamin terbanyak adalah perempuan dengan representasi 58,33\% menunjukan $16,66 \%$ responden tidak sekolah, 5,55\% tamat $\mathrm{SD}, 8,33$ \% tamat SMP, 36,22 tamat SMA, dan 33,33 berpendidikan $\mathrm{S} 1$.

Tabel 2. Tingkat stress sebelum dan sesudah diberikan terapi teknik relaksasi otot progresif

\begin{tabular}{|c|c|c|c|c|}
\hline $\begin{array}{c}\text { Tingkat } \\
\text { Stress }\end{array}$ & $\begin{array}{c}\text { Mea } \\
\text { n }\end{array}$ & N & CI95\% & $\begin{array}{c}\boldsymbol{P} \\
\text { value }\end{array}$ \\
\hline Sebelum & 16,75 & 36 & $16,19-17,30$ & 0,000 \\
\hline Sesudah & 11,58 & 36 & $11,07-12,09$ & \\
\hline
\end{tabular}

Berdasarkan data pada Tabel 2 dapat diperoleh nilai rata-rata skor tingkat stress sebelum intervensi sebanyak 16,75 dan mengalami penurunan skor stress setelah diberikan intervensi teknik relaksasi otot progresif 11,58. Nilai rata-rata skor stress masyarakat menunjukan adanya penurunan setelah diberikan terapi teknik relaksasi otot progresif 5,16 dengan $\mathrm{p}$ value 0,000 lebih kecil dari $\alpha=0,05$ artinya ada pengaruh yang signifikan pemberian terapi teknik relaksasi otot progresif terhadap penurunan tingkat stress masyarakat dimasa pandemic COVID-19.

\section{Pembahasan}

Responden memiliki berbagai sumber stres yang dapat memicu timbulnya stres seperti lingkungan dan komunitas. Apalagi dimasa pandemic COVID-19 seperti saat ini semua aktivitas serba terbatas. Dan banyak pekerjaan harus diselesaikan dirumah, sedangkan tidak efektivnya pekerjaan membuat menumpuknya pekerjaan dan memicu terjadinya stress.

Berdasarkan hasil penelitian ini menunjukan ada pengaruh yang signifikan terhadap penurunan tingkat stress pada masyarakat setelah diberikan teknik relaksasi otot progresif. Penelitian ini sejalan dengan penelitian yang dilakukan oleh Arisjulyanto (2017) yang menyatakan ada pengaruh teknik relaksasi otot progresif dalam menurunkan tingkat stress dan tekana darah apsien hipertensi. Dan sejalan dengan penelitian yang dilakukan oleh Ilmi et al., (2017) ayang menunjukan ada pengaruh teknik relaksasi otot progresif terhadap menurunkan tingkat kecemasan dan stress narapidan wanita. Dan penelitian serupa dilakukan oleh Lestari \& Yuswiyanti (2015) menyatakan relaksasi otot progresif sangat efektiv dalam menurunkan tingkat kecemasan dan stress pasien.

Menurut Casey \& Benson (2006) Respon yang didapatkan secara fisiologis tubuh akan mengalami respon yang dinamakan respon fight or flight. Dimana korteks otak menerima rangsangan yang dikirim melalui saraf simpatis ke kelenjar adrenal yang akan melepaskan adrenalin atau epineprin sehingga efeknya antara lain napas menjadi dalam, nadi meningkat, dan tekanan darah meningkat. Respon ini memerlukan energi cepat, sehingga hati melepaskan lebih banyak glukosa menjadi bahan bakar otot dan terjadi pula pelepasan hormon yang menstimulasi perubahan lemak dan protein menjadi gula.

Hal tersebut juga diperkuat dengan pernyataan Triyanto (2014) dalam buku Pelayanan Keperawatan Bagi Penderita Hipertensi Secara Terpadu mengatakan Teknik relaksasi menghasilkan respon fisiologis yang teritegrasi dan juga mengganggu bagian dari kesadaran yang dikenal sebagai "respon relaksasi benson". Respon relaksasi diperkirakan menghambat sistem syaraf otonom dan sistem saraf pusat dan meningkatkan aktivitas parasimpatis yang dikarakteristik dengan menurunnya otot rangka, tonus otot jantung dan mengganggu fungsi neuroendokrin.

Agar memperoleh manfaat dari respon relaksasi, ketika melakukan teknik ini diperlukan lingkungan yang tenang, posisi yang nyaman dan dapat menggunakan rekaman latihan relaksasi berupa tape. Alat ini akan membantu pasien memfokuskan perhatian (konsentrasi) pada pelepasan ketegangan otot di setiap otot-otot tubuh yang utama sambil merasakan irama pernafasan. Terapi relaksasi merupakan salah satu teknik pengelolaan diri yang didasarkan pada cara kerja system syaraf simpatis dan parasimpatetis ini. Teknik relaksasi semakin sering dilakukan karena terbukti efektif mengurangi ketegangan dan kecemasan, penelitian relaksasi progresif sudah 
cukup banyak dilakukan. Terapi relaksasi progresif terbukti efektif dalam menurunkan kecemasan dan stress(Arisjulyanto, 2017; Triyanto, 2014).

\section{Kesimpulan}

Terdapat pengaruh relaksasi otot progresif terhadap perubahan tingkat stress pada masyarakat di Kabupaten Lombok Tengah. Sehinga petugas kesehatan dapat memberikan edukasi terkait penggunaan terapi relaksasi otot progresif dan pelatihan relaksasi otot progresif sebagai terapi untuk menurunkan stres di Kabupaten Lombok Tengah.

\section{DAFTAR PUSTAKA}

Arisjulyanto, D. (2017). Pengaruh teknik relaksasi otot progresif terhadap penurunan tekanan darah pada pasien hipertensi di Puskesmas Cakranegara tahun 2016. Berita Kedokteran Masyarakat, 33(11).

Arisjulyanto, D. (2018). Primary Health Care : Open Access The Effect of Progressive Muscle Relaxation Techniques to Decrease Blood Pressure for Patients with Hypertension in Mataram. Primary Health Care, 8(4), 10-13. 1079.1000309

Ausrianti, R., Andayani, R. P., Surya, D. O., \& Suryani, U. (2020). EDUKASI PENCEGAHAN PENULARAN COVID 19 SERTA DUKUNGAN KESEHATAN JIWA DAN PSIKOSOSIAL PADA PENGEMUDI OJEK ONLINE Rizka. Jurnal Peduli Masyarakat, 2, 59-64.

Casey, A., \& Benson, H. (2006). Menggunakan Respon Relaksasi Untuk Menurunkan Tekanan Darah. alih bahasa Nirmala Dewi, Jakarta: Jakarta: PT. Bhuana Ilmu Populer.

Dinkes NTB. Laporan Kasus COVID-19 Provinsi NTB (2020).

Ilmi, Z. M., Dewi, E. I., \& Rasni, H. (2017). Pengaruh Relaksasi Otot Progresif Terhadap Tingkat Stres Narapidana Wanita di Lapas Kelas IIA Jember ( The Effect of Progressive Muscle Relaxation on Women Prisoners' $s$ Stress Levels at Prison Class IIA Jember ). E-Jurnal
Pustaka Kesehatan, 5(3), 497-504.

Ivancevich, Konopaske, \& Matteson. (2006). Perilaku dan Manajemen Organisasi. Jakarta: Erlangga.

Lestari, K. P., \& Yuswiyanti, A. (2015). PENGARUH RELAKSASI OTOT PROGRESIF TERHADAP PENURUNAN TINGKAT KECEMASAN PADA PASIEN PRE OPERASI DI RUANG WIJAYA KUSUMA RSUD DR. R SOEPRAPTO CEPU. Jurnal Keperawatan Maternitas, 3(1), 27-32.

Mona, N. (2020). Konsep Isolasi Dalam Jaringan Sosial Untuk Meminimalisasi Efek Contagious (Kasus Penyebaran Virus Corona Di Indonesia). Jurnal Sosial Humaniora Terapan., 2(2).

Muslimin. (2017). TERAPI TASAWUF SEBAGAI UPAYA PENANGGULANGAN STRESS, DEPRESI, DAN KECEMASAN. Ghaidan: Jurnal Bimbingan Konseling Islam Dan Kemasyarakatan /, 1(1), 1-26.

Purwanto, A. (2020). Studi Eksplorasi Dampak Work From Home (WFH) Terhadap Kinerja Guru Selama Pandemi Covid-19. EduPsyCouns Journal, 2(1), 92-100.

Triyanto, E. (2014). Nursing Services for Hypertension Patients Integrated. Yogyakarta: Graha Ilmu. WHO. (2020). Data COVID 19. 